\title{
The Dolomites UNESCO World Heritage: visitors' mobility behaviour and acceptance of regulatory measures
}

\author{
Thomas Streifeneder \& Andrea Omizzolo
}

Keywords: world heritage, Dolomites, Alps, travel behaviour, tourism intensity, mobility, protected areas, modal choice

\section{Abstract}

In 2009 the Italian Dolomites became serial Natural World Heritage property. Due to the high intensity of tourism, with large tourist flows and overcrowded hotspots in the summer and winter seasons causing severe pressure on the environment, the IUCN required a comprehensive strategy for sustainable tourism mobility, which was devised by EURAC Research. This report presents selected results on the travel patterns in the access to the Dolomites. It highlights the tourists' modal choice motivation and their willingness to accept regulatory measures.
Profile

Protected area

Dolomites UNESCO WH

Mountain range

Alps

Country

Italy

\section{Introduction}

Protected areas (PAs) are important tourist attractions, which create economic benefits and sustainable local development and also boost tourism in the surrounding areas (Conradin \& Wiesmann 2014; Mayer \& Job 2014; Ruoss 2016). They provide an ideal setting for the growing heterogeneous market of naturebased tourism (Butzmann \& Job 2016; OPTN 2016). Crowding in hotspots impacts on the natural environment and puts the attractiveness of PAs and the tourist experience itself at risk (Schamel \& Job 2013). Mobility in PAs severely affects the environment and land use as a result of motorized individual transport (Kagermeier \& Gronau 2016). Almost $94 \%$ of the $\mathrm{Al}-$ pine tourists travel by car (PSAC 2013).

The environmental effects are exacerbated in PAs because of the specific geomorphological setting and the geographical and seasonal concentration of traffic (INFRAS / IFEU 2011). Visitor experience analysis, tourist flow planning and resource protection measures therefore are relevant PAs management instruments (Job \& Vogt 2003; Manning 2002; Manning et al. 2014). The German Alpine Plan (Alpenplan), for example, focuses on territorial planning measures and specific public infrastructure to steer tourism flows (Job et al. 2014). In this context, core and buffer zones play a key role (Butzmann \& Job 2016). Modern information and communication technologies like GPS-enabled mobile devices will influence visitor management (Job et al. 2016). Nevertheless, regulatory measures do not guarantee success, since mobility choices largely depend on the motivation of each tourist. Hedonistic travellers, for instance, are less willing to make compromises for the benefit of the environment (Swarbrooke 1999).
Travel behaviour measures play a crucial role in visitor management. Generally these can be divided into hard management disincentives (push-measures to influence individual travel decisions, e.g. parking fees and road tolls) and soft management incentives (pull-measures to make alternative forms of transport more attractive, e. g. shuttle buses) (Lopez Lambas \& Ricci 2014; Steiner \& Bristow 2000; Stanford 2014). Push and pull measures combined are more effective and better accepted than one single measure (Eriksson et al. 2008).

Serial Natural World Heritage properties like the Dolomites face particular challenges from tourism due to their various access points. However, only a few studies (Engels 2009; IUCN 2009) provide any findings about serial PAs.

\section{The Dolomites UNESCO World Heritage}

The Dolomites are situated in the north-eastern Italian Alps. On 26 June 2009, nine areas were inscribed in the UNESCO World Heritage List for the universal value of their exceptional geology and beauty of the outstanding mountain landscape. The serial character of the property results in a complex governance system and protection status. A specific foundation (the UNESCO Dolomites Foundation) was set up for co-ordinated management. Its operational bodies are the Steering Committee, the Board of Auditors, the Scientific Committee and the Board of Supporters (http://www.dolomitiunesco.info). On 24 October 2016 the Overall Management Strategy was put on the foundation website and can be downloaded from there (ibid.). However, the overall management system with an inter-provincial governance arrangement is not fully functional yet (http://whc.unesco. 


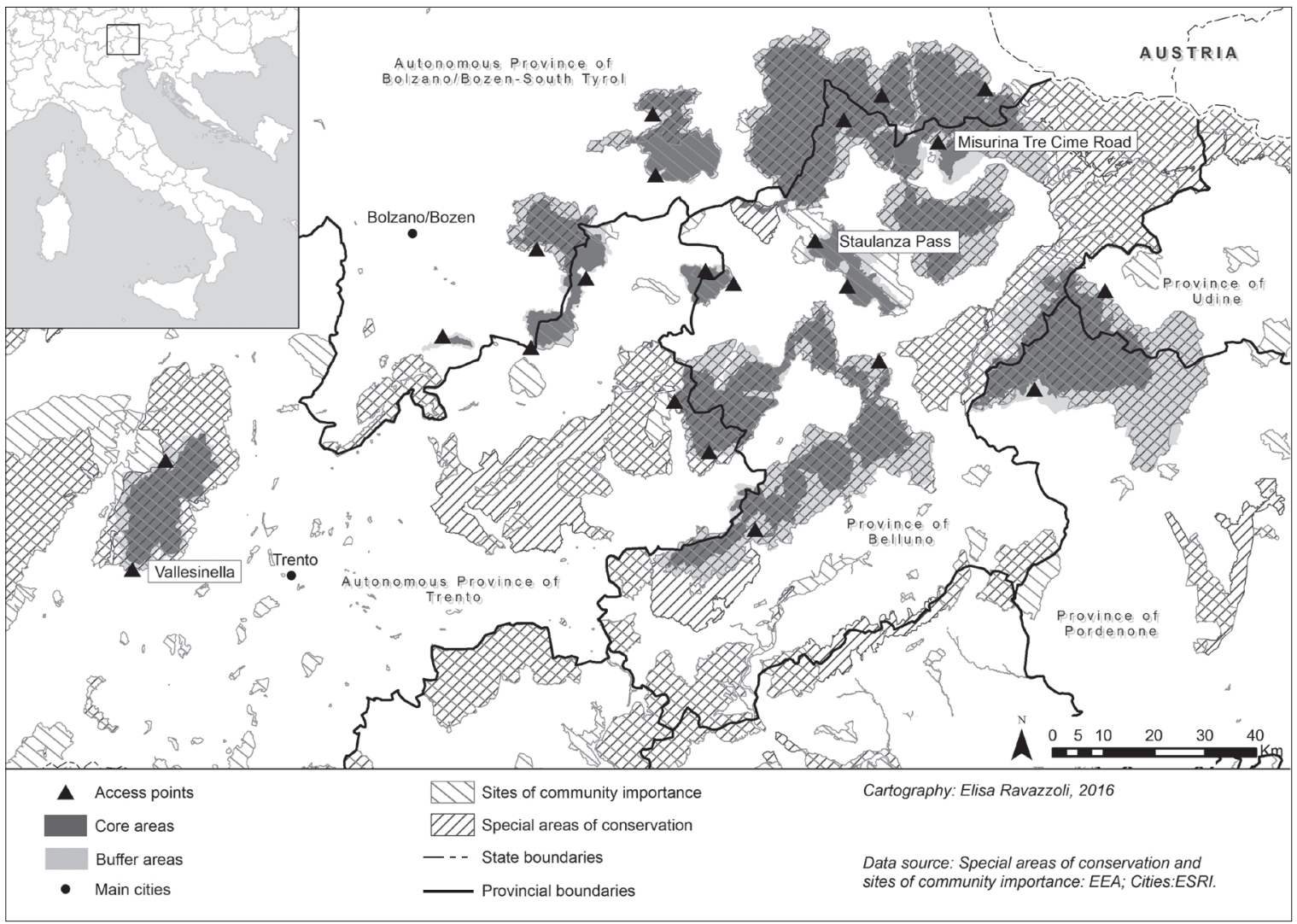

Figure 1 - Overview of the Dolomites UNESCO World Heritage Sites.

org/en/list/1237). Three Italian regions (TrentinoAlto Adige, Friuli-Venezia Giulia and Veneto), five provinces (Bolzano/Bozen, Trento, Belluno, Udine and Pordenone) and over 130 municipalities belong to this World Heritage Site (see Figure 1). There are more than 100 access points to the area, $80 \%$ of the site is protected and includes one national park, eight provincial nature parks and several Natura 2000 sites. More than 29 million overnight stays per year have been registered in the municipalities directly bordering on the UNESCO World Heritage Site (ASTAT 2016). In summer and winter, tourism intensity is very high (see Figure 2). Because of these conditions, EURAC Research was commissioned to create the scientific basis for a strategic plan for tourism development.

In summer 2013 EURAC conducted a quantitative survey at 21 selected access points to the nine component areas of the site. The questionnaire also dealt with mobility behaviour and mobility patterns, including the modes of transport used to access the PAs on the day of the survey. We interviewed 6110 individuals, $60.7 \%$ men, $39.3 \%$ women, mainly hikers $(64.5 \%)$ coming from the north-east of Italy $(73 \%)$ and from Germany (18\%). In this report we focus on the results of tourists' behaviour and expectations at three representative access points with high tourism intensity (see Table 1).
Table 1 - The characteristics of the three case study access points.

\begin{tabular}{|l|l|}
\hline Access point & Characteristics \\
\hline $\begin{array}{l}\text { Staulanza Pass } n=256) \\
\text { Misurina-Tre Cime }\end{array}$ & $\begin{array}{l}\text { located in Pelmo - Croda da Lago } \\
\text { area / Province of Belluno } \\
- \text { poor accessibility by public transport } \\
\text { - }\end{array}$ \\
high level of access by individual trans- \\
port
\end{tabular}

\section{Modal split and the acceptance of visitor management measures}

Coherent with other studies, the tourists visiting the Dolomites prefer to use individual motorized transport (see Figure 3; overall average 79\%). This is especially true of the Staulanza Pass $(90 \%)$, which is poorly served by public transport and remote from the main touristic centres. The parking fee significantly in- 


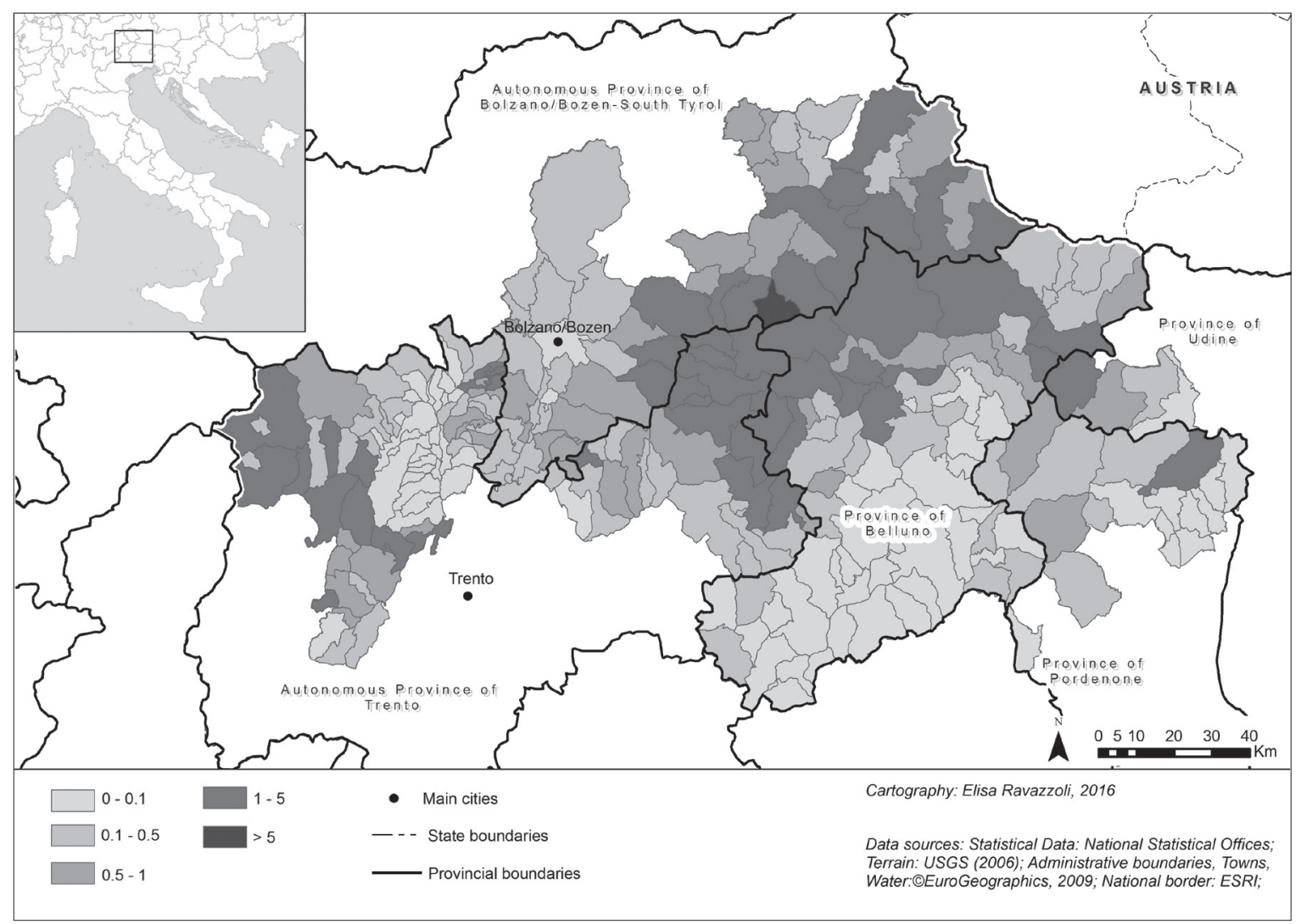

Figure 2 - Tourism intensity 2011. The index is calculated as follow: $T I=N / P$ where $N$ is the number of beds in hotels and similar establishments and $P$ is population

fluences access to Misurina Tre Cime, where private vehicles make up 56\%. We registered a similar situation at the Vallesinella access with the same parking fee system (55\%). An analysis of the origin of the visitors arriving at the Misurina Tre Cime access by public transport (31\%) showed that the broader public transport service in the province of Bolzano, compared to the province of Belluno, resulted in a higher number of visitors using public transport (51\% vs. $33 \%)$. This is mainly due to the higher frequency of South Tyrolean public transport.

Concerning the tourists' acceptance of measures limiting private motorized access, we present the results of two types of measures as examples:

- Push measure: road toll.

- Pull measure: shuttle bus service (criteria: two rides there and back on a Sunday during the main season).

The interviewees at Staulanza Pass expressed a greater readiness to accept a road toll and consequently they showed the lowest acceptance rate for shuttle buses and parking fees (see Figure 4). This also results from the poor accessibility by public transport, and, moreover, this access point attracts a high number of hedonistic travellers. They prefer unlimited access by motorized individual vehicles and are willing to pay for continuing to have this option. In line with previous studies (Orsi 2015), we also observed a higher level of acceptance of a shuttle bus compared to a parking fee.

\section{Discussion and conclusion}

The results generally confirm previous research done in this field, illustrating that pull measures generally tend to be better accepted by visitors than push measures (Cullinane \& Cullinane 1999). Nevertheless, the acceptance of both types of measures is related to the specific characteristics of the visited site. In areas fully accessible to hedonistic visitors using private transport, they rather accept a fee to maintain the habit of using private motorized transportation. For this type of areas it can be assumed that such measures would generate revenues, but would not lead to a reduction of private motorized traffic. This is confirmed by the observations of the case study at the Misurina Tre Cime road, where an access fee is already in force, but has not had a significant effect on the number of visitors arriving by private transport. Where a combination of push and pull measures have been put into effect, visitors are more willing to accept both types of measures. This endorses previous studies highlighting a broader public acceptance when push and pull measures are implemented in the same policy package (Eriksson et al. 2008).

The results illustrate that a general panacea for the mitigation of increased individual motorized traffic in PAs does not exist but is related to pre-existing measures and the characteristics of the site. Tailor-made measures for specific access points are necessary, 


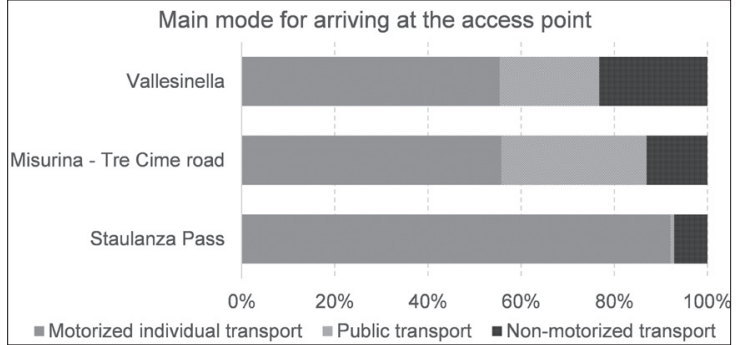

Figure 3-Modal choice in the selected accesses.

which implies an analysis of all access points and the development of specific measures.

\section{Acknowledgements}

This report is based on preliminary work, the final unpublished report Turismo sostenibile nelle Dolomiti. Una strategia per il Bene Patrimonio dell'Umanità Unesco, written by Matthias Wagner and Marianna Elmi, and the unpublished results of the project Turismo Sostenibile nelle Dolomiti, approfondimento dell'analisi, written by Marianna Elmi, all devised by EURAC Research.

\section{References}

ASTAT (Regional Office of Statistics) 2016. Entwicklung im Tourismus - Tourismusjahr 2014/15. ASTAT Info 26. Bozen. [In German]

Butzmann, E. \& H. Job 2016. Developing a typology of sustainable protected area tourism products. Journal of Sustainable Tourism 1-20.

Conradin, K. \& U. Wiesmann 2014. Does World Natural Heritage status trigger sustainable regional development efforts? eco.mont 6(2): 5-12.

Cullinane, S.L. \& K. Cullinane 1999. Attitudes towards traffic problems and public transport in the Dartmoor and Lake District National Parks. Journal of Transport Geography 7: 79-87.

Elmi, M. \& M. Perlik 2014. From tourism to multilocal residence? Unequal transformation processes in the Dolomites area. Journal of Alpine Research 102(3). Available at: https://rga.revues.org/2608

Engels, B. 2009. Serial Natural World Heritage Properties - Challenges for Nomination and Management. Proceedings of the workshop organised by the German Federal Agency for Nature Conservation $11^{\text {th }}$ November 2009. Available at: https://www.bfn.de/fileadmin/MDB/ documents/themen/internationalernaturschutz/ SerialSites\%20Summary\%20Report_2009.pdf.

Eriksson, L., J. Garvill \& A.M. Nordlund 2008. Acceptability of single and combined transport policy measures: the importance of environmental and policy specific beliefs. Transportation Research Part A: Policy and Practice 42(8): 1117-1128.

INFRAS/IFEU (ed.) 2011. ÖV und Umwelt. Herausforderungen und Handlungsbedarf. Bern and Heidelberg. [In German]

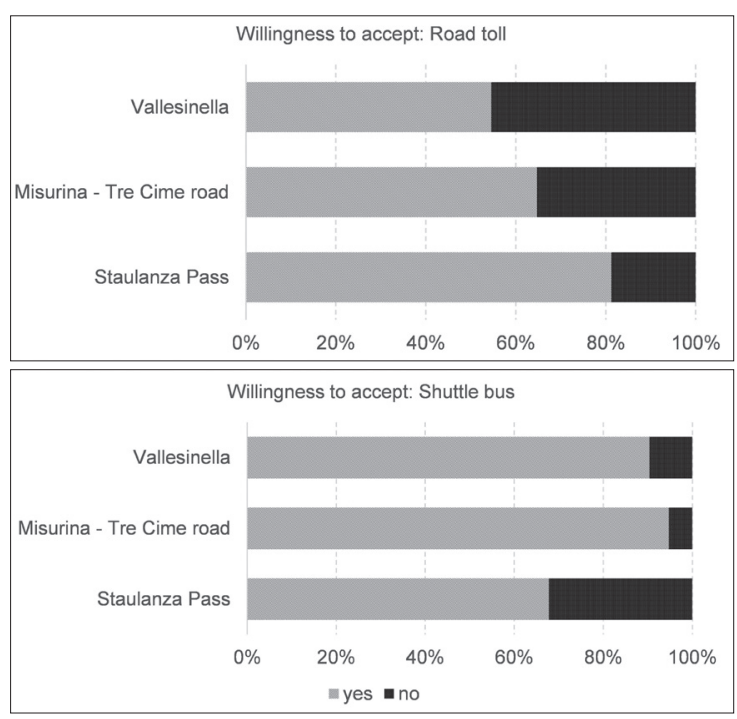

Figure 4 - Willingness to accept having to pay, two management measures.

IUCN - International Union for Conservation of Nature 2009. An initial analysis of the present situation of serial natural World Heritage properties. IUCN World Heritage Studies 6. Available at: http://cmsdata. iucn.org/downloads/world_heritageserialsites.pdf.

Job, H., J. Schamel \& E. Butzmann 2016. Besuchermanagement in Großschutzgebieten im Zeitalter moderner Informations- und Kommunikationstechnologien. Natur und Landschaft 91(1): 32-38.

Job, H., M. Mayer \& F. Kraus 2014. Die beste Idee, die Bayern je hatte: der Alpenplan. Gaia 23(4): 335345.

Job, H. \& L. Vogt 2003. Freizeit/Tourismus und Umwelt - Umweltbelastungen und Konfliktlösungsansätze. In: Becker, C., H. Hopfinger \& A. Steinecke (eds.), Geographie der Freizeit und des Tourismus: Bilanz und Ausblick. München: 851-864. [In German]

Kagermeier, A. \& W. Gronau 2016. Umweltverträgliche ÖPNV-Angebote in Großschutzgebieten: Schlüsselfaktoren und Voraussetzungen. Jahrestagung des Arbeitskreises Tourismusforschung 2016: Naturtourismus - Chancen und Herausforderungen, 25.-27. Mai 2016, Nationalpark Bayerischer Wald/Zwiesel. [In German]

Lopez Lambas, M.E. \& S. Ricci 2014. Planning and management of mobility in natural protected areas. Procedia - Social and Behavioral Sciences 162: 320-329.

Manning, R., S. Lawson, P. Newman, J. Hallo \& C. Monz 2014. Principles of Sustainable Transportation in the National Parks. The George Wright Forum 31(3): 345-358.

Manning, R.E. 2002. Monitoring and Management of Visitor Flows in Recreational and Protected Areas. In: Arnberger, A., C. Brandenburg \& A. Muhar (eds.), Conference Proceedings How Much is Too Much? Carrying Capacity of National Parks and Protected Areas: 306-313.

Mayer, M. \& H. Job 2014. The economics of protected areas - a European perspective. Zeitschrift für Wirtschaftsgeographie 58: 73-97. [In German] 
OPTN - Osservatorio Permanente sul Turismo Natura (ed.) 2016. $13^{\circ}$ Rapporto Ecotur sul Turismo Natura. Available at: http://www.ecoturnatura.eu/ wp-content/uploads/2016/04/13Rapporto.pdf [In Italian]

Orsi, F. (ed.) 2015. Sustainable transportation in natural and protected areas. Routledge Studies in Transport, Environment and Development. London, New York.

Ruoss, E. 2016. Opportunities to leverage World Heritage Sites for local development in the Alps. eco. mont 8(1): 53-61.

Schamel, J. \& H. Job 2013. Crowding in Germany's national parks: the case of the low mountain range Saxon Switzerland National Park. eco.mont 5(1): 27-34.

Stanford, D.J. 2014. Reducing visitor car use in a protected area: a market segmentation approach to achieving behaviour change, Journal of Sustainable Tourism 22(4): 666-683.

Steiner, T.J. \& A.L. Bristow 2000. Road-pricing in national parks: A case study in the Yorkshire Dales National Park. Transport Policy 7: 93-103.

PSAC - Permanent Secretariat of the Alpine Convention (ed.) 2013. Sustainable Tourism in the Alps. Report on the state of the Alps. Innsbruck.
Swarbrooke, J. 1999. Sustainable tourism management. Wallingford: CABI International.

\section{Authors}

\section{Thomas Streifeneder ${ }^{1}$}

is an economic geographer and head of the Institute for Regional Development and Location Management of EURAC Research. Key research interests are regional development, agricultural and socio-economic dynamics in mountain regions, intersectoral cooperation and interdisciplinary approaches. E-mail: thomas.streifeneder@eurac.edu

\section{Andrea Omizzolo'}

is an expert in territorial planning and management at the Institute for Regional Development and Location Management of EURAC Research. His key areas of interest are nature, landscape and spatial development, natural park management plans and monitoring of socio-economic mountain development.

${ }^{1}$ Eurac Research, Institute for Regional Development, Viale Druso 1, I-39100 Bolzano, Bozen 